\title{
A Scoping Review on Practicum of Turkish Pre-Service EFL Teachers during COVID-19
}

\section{Ayşe Kızıldağ ${ }^{1}$ | Hülya Tuncer ${ }^{2}$}

\author{
${ }^{1}$ Asst. Prof. Dr., Aksaray \\ University, Aksaray/Turkey \\ ORCID: 0000-0002-7717-256X \\ E-Mail: \\ akizildag@aksaray.edu.tr \\ 2 Dr., Çukurova University, \\ Adana/Turkey \\ ORCID: 0000-0001-8536-6471 \\ E-Mail: hulyatan@cu.edu.tr \\ Corresponding Author: \\ Ayşe Kızıldağ \\ January 2022 \\ Volume:19 \\ Issue: 45 \\ DOI: $10.26466 / /$ opusjsr.1063236
}

Citation:

Kızlldağ, A. and Tuncer, $\mathrm{H}$

(2022). A scoping review on practicum of Turkish pre-service EFL teachers during COVID-19. OPUS- Journal of Society Research, 19(45), 129-142.

\begin{abstract}
The practicum period is a crucial component of teacher education as it embodies the first phases into "real" teaching and thus provides a leap into professional transformation and growth on the side of preservice teachers. Nevertheless, the COVID-19 pandemic jeopardized this period and placed the educational contexts at stake in providing that reality. Within this frame, the present study focuses on the research conducted on the practicum period of Turkish pre-service teachers of English during the pandemic. More specifically, the research question that the article addresses is "what is the nature of studies conducted about Turkish pre-service EFL teachers' practicum period during the COVID-19 pandemic concerning their characteristics, methodologies and contributions to the field?" With the aim of answering the research question, the seven studies conducted in Turkey regarding the practicum during the pandemic were collected and analyzed as to their bibliographic features, methodological orientations, foci and context, with a scoping review methodology. This scoping review demonstrated both positive/beneficial and negative/challenging aspects of the pandemic period for the English language teacher education context of Turkey. The results of the present study displayed a wider lens in perceiving the English language teaching and teacher education settings during both such emergencies and transition from existing to 'new normal'.
\end{abstract}

Key Words: Practicum, English Language Teaching, Pre-Service EFL Teachers, Scoping Review, COVID-19.

Öz

Staj uygulamaları, öğretmen adaylarının ilk "gerçek" öğretim aşamasını oluşturması ve dolayısıyla mesleki dönüşüm ve gelişime bir geçiş sağlaması nedeniyle, öğretmen eğitiminin çok önemli bir dönemidir. Fakat COVID-19 salgını bu dönemi tehlikeye sokmuş bu gerçekliğin yerine getirilmesi görevini de eğitim kurumlarma yüklemiştir. Bu çerçevede, çalışmamız salgın esnasında Türkiye'de İngilizce Öğretmenliği bölümlerinde okuyan öğrencilerin staj sürecini kapsayan yayınlanmış diğer çalıșmalara odaklanmaktadır. Daha net ifadeyle, bu makale, "COVID-19 salgını strasında Türkiye'de İngilizce Öğretmenliği Bölümlerinin staj uygulamaları kavramını ele alan çalışmaların özellikleri, metotları ve alana katkıları açısından doğası nedir?" araştırma sorusunu cevaplamayı amaçlamaktadır. Bu soruyu cevaplamak için, Türkiye'de salgın esnasında İngilizce Öğretmenliği bölümlerinde okuyan öğrencilerin staj uygulamalar deneyimi sürecine odaklanan çalışmalar taranmış ve toplamda yedi yayına ulaşılmıştır. Bu çalışmaların yayın özellikleri, metodolojik yaklaşımları ile amaç ve bağlamları, kapsam analizi metoduyla analiz edilmiştir. Kapsam analizi, salgin sürecinin Türkiye'deki İngilizce öğretmeni eğitimine pozitiflyararlı ve negatif/zorlayıcı etkilerini gözönüne sermiştir. Bulgular, İngilizce öğretimi ve öğretmen yetiştirme çerçevesinde varolandan 'yeni normal'e geçişte geniş bir bakış açısına erişimde katkılar sunmaktadır.

Anahtar Kelimeler: Staj Uygulamaları, İngilizce Öğretimi, Öğretmen Adayları, Kapsam Analizi, COVID-19. 


\section{Introduction}

Online learning, though not a new concept for education sector, has become a priority since pandemic breakout in March 2020 for the decisionmaking authorities of education globally (e.g., Departments of Education), and the agents such as school managers, teachers, students and their families. With the closure of schools, teachers quickly had to adopt online teaching, teacher education included. This rapid and forced change brought many challenges and constraints to the regular practices due to poor online infrastructure, teachers' lack of experience and inadequate digital skills, inappropriate home environment (König et al., 2020; Zhang et al., 2020). Additionally, problems about teachers' having unsatisfactory support and mentoring for using such platforms in teaching were also reported (Huber \& Helm, 2020; Judd et al., 2020). Similar results were found in various studies conducted at tertiary levels (Ali, 2020; Huang, 2020; Karataş \& Tuncer, 2020; Mishra et al., 2020; Paudel, 2021).

Swift transition from face-to-face to online platforms in teaching added extra responsibilities to foreign language teacher education institutions, particularly in practice-nature courses such as practicum considering the fact that all teaching activities are transferred to online platforms. In fact, before the virus outbreak, there was already a positive body of literature that suggested integrating ICT into pre-service teacher education taking into account online learning mode offers active engagement and higher level thinking in supportive group works as well as improving digital literacy (Bahcivan et al., 2019; Brown, 2014; Forbes \& Khoo, 2015; Gillies, 2008; Kibar \& Ozer, 2020; Weschke et al., 2011). Yet, the suggestion was a blended approach rather than holistic.

Practicum is the integral and key part of a teacher education program (Anderson \& Stillman, 2013; Smith \& Lev-Ari, 2005). Face-to-face interaction in English pre-service teachers' learning to teach is extremely significant to enable theory and practice interactions under the guidance of a mentor and a university supervisor (Allen \& Wright, 2014; Darling-Hammond, 2017).
Clinical experience also allows to experience actual school context and closely observe student profiles, and helps to develop more realistic expectations from the professional settings (Farrell, 2008; Seferoğlu, 2006; Tülüce \& Çeçen, 2016; Yangin Eksi \& Gungor, 2018).

In Turkey, practicum is conducted with two courses during the fourth year of the EFL teacher education curriculum currently. It has two segments: In the fall semester, pre-service teachers are placed at one of the local primary, middle or high schools, and there they conduct classroom observations with various pedagogical foci such as classroom management, teacher-student roles and practices, instructional design and assessment during the course called School Experience. A total of 14 weeks spent at schools with an assigned mentor and an accompanying university supervisor working collaboratively to ensure that pre-service teachers allocate at least four hours of classroom observation weekly constitute the first part of the practicum process. Each week, with preassigned observation tasks, student teachers prepare their field notes and write reflective reports for both the mentor and the supervisor while discussing the issues that emerged and receiving feedback, respectively. They carry out critical and reflective dialogues with their university supervisor during one class hour on campus. They are assessed upon their respective reflective performance as well as task completion.

In the spring semester, student teachers take another 14-week practicum course, namely Practice Teaching, as the second phase of the practicum process. This time, they spend at least six hours during 12 weeks in the classroom not only for observations but also practice teaching. They have to perform at least four micro-teaching, two peer-assessments and one fully planned teaching to be assessed for a final. After each performance, they also generate mentor and supervisor feedback within two classroom hours on campus.

Nevertheless, the practicum phase is still perceived as the most critical and challenging part of teacher education programs as well (Corcoran, 1981; Ewing \& Smith, 2003; Gold, 1996; Kane, et al., 
2006) being important and the best part (FeimanNemser, 2001; Smith \& Lev-Ari, 2005). A study by Başaran Uysal and Savaş (2021) analysing the practicum studies conducted in the field of EFL teacher education in the Turkish context, categorize the issues encountered within seven domains: mentor, supervisor, school, practice teaching, practicum, language, theory and practice relation. Underqualified mentors for assisting preservice teachers professionally during the school visits, careless and unmotivated mentor attitudes, lack of feedback from the university supervisors who often pay no or very few visits to schools are among the problems reported by mentors and supervisors. Moreover, lack of technological infrastructure, uninterested and misbehaving students in classes, and attitudes like not being accepted as teachers by managers are problems originating from practice schools. Practice teaching itself poses a big challenge for pre-service teachers in that they are expected to handle many tasks in tandem with the class flow such as classroom management, planning and executing the tasks, giving comprehensive instructions, and managing mixed-ability student learning. This all at once requirement of the practicum process putting student teachers in a difficult state during the 4th year, when they take practicum courses, is already a time when most are busy with preparation for the teacher certification test (KPSS-Selection Examination for Professional Posts in Public Organizations). They also have to cope with target language proficiency where most of the conversation in class has to be in English. Linguistic problems experienced are also realized while teaching language components to students, which, in turn, creates a big anxiety. Last but not least is theory and practice discrepancy.

Transforming to remote teaching during the pandemic, practicum courses have also been moved into online classes. As a result, school placements are conducted from home. Beset with many problems even before the pandemic (Başaran Uysal \& Savaş, 2021), the practicum process added more tasks onto the agents (i.e., schools, faculties, teachers, academics, and naturally student teachers) during the lockdown. Due to ongoing remote teaching practices, EFL teacher education departments had to resolve not only aforementioned practicum issues but also emerging ones during e-practicum. With the circular letters sent to all universities by the Turkish Higher Education Council (HEC) that practicum in teacher education faculties had to be conducted online and only university-based and fully online with school-university partnerships onwards October 2020. Thus, practice teaching has been realized both only university- based and via school online platforms during three academic terms that the pandemic lasted in Turkey. The Ministry of National Education decided to conduct online classes on its intranet called Education Information Network (known as EBA) since the beginning of the coronavirus outbreak. However, the first challenge for universities emerged when pre-service teachers who would not log into EBA for observing and performing teaching activities. Therefore, mentors moved their teaching to the Zoom platform.

What happened, after all, during the practicum process is the main concern of this scoping review. Studies conducted on practicum processes of EFL teacher candidates during the pandemic are analyzed to shed light how pre-service teachers, schools and universities handled the practicebased procedures. What type of topics are significant and what other problems and opportunities emerged in such studies are the focus in that this new normal seem to be opening new pathways for near future practices of teacher education programs.

\section{Method}

\section{Study Design}

This study is designed as a scoping review (Arksey \& O'Malley, 2005). A five-step framework proposed by Arksey and O'Malley (2005) highlights the high level of transparency and repeatability of searching strategy for reliability purposes of the findings. Scoping review is accepted as a powerful methodological tool since it addresses a large variety of topics including various study designs unlike systematic reviews, nor meta analyses where only quantitative research design and statistical results are collated and summarized. The framework of Arksey and 
O'Malley (2005) follows the guidelines for identifying the research question and relevant studies, selecting the studies to be analyzed, plotting the data and finally assembling, summarizing and reporting the findings, respectively. Since our aim is to display the main characteristics and trends on the topic in question, we choose to employ the scoping review approach to see the nature of studies conducted in a particular context, i.e., Turkish pre-service EFL teachers' practicum studies during the COVID-19 pandemic where fully online education protocols were implemented between March 2020 to September 2021.

\section{Data Collection}

The first step we realized was to define the research question with the relevant studies. Our research question is,

What is the nature of studies conducted during the COVID-19 pandemic in the topic of Turkish pre-service EFL teachers' practicum period in terms of their characteristics, methodologies and contributions to the field?

As can be realized from this research question, the scope of the current study is focusing on the publications about EFL pre-service teachers' practicum period during the COVID-19 pandemic, from March 2020 to the submission of the manuscript. Building the time and context boundaries helped us ensure the validity of the current study while realizing the second step for data collection.

The second step was to select the studies to be analyzed. For this, we went through databases of Google Scholar, ULAKBIM-TR, ERIC, Scopus, Web of Science, EBSCO Academic, JSTOR, ProQuest, and Thesis Center of HEC where we used a number of key word combinations, COVID19, practicum, practice teaching, school experience, EFL, pre-service teachers, English, Turkey, Turkish. Selection was based on the articles conducted only during the pandemic (i.e., March 2020-October 2021) when schools went fully online and in the Turkish context with EFL pre-service teachers. Publications both in Turkish and English were included. Blogs, institutional reports, white/green/blue/yellow papers, press releases, news, online posts and informative websites were excluded. As for the third step, we have come up with six peer-reviewed articles and a book chapter as given below. Given the time constraint, the number of the publications to be analyzed is understandably found to be limited. Studies are ordered alphabetically and each is given a code (i.e., S1, S2, and so on) for further reference in the findings section.

S1: Ersin, P.,\& Atay, D. (2021). Exploring online mentoring with preservice teachers in a pandemic and the need to deliver quality education. International Journal of Mentoring and Coaching in Education, 10(2), 203-215.

S2: Ersin, P., Atay, D., \& Mede, E. (2020). Boosting preservice teachers' competence and online teaching readiness through e-practicum during the COVID-19 outbreak. International Journal of TESOL Studies, 2(2), 112-124.

S3: Gök Çolak, F., \& Efeoğlu, G. (2020). Yeni normalleşme sürecinde öğretmenlik uygulaması dersine yönelik ihtiyaç analizi: SWOT analizi örneği. Kesit Akademi Dergisi, 7(27), 176-197.

S4: Korucu-K1ş, S. (2021). Preparing student teachers for real classrooms through virtual vicarious experiences of critical incidents during remote practicum: A meaningful-experiential learning perspective. Education and Information Technologies, 26, 6949-6971.

S5: Koşar, G. (2021). Distance teaching practicum: Its impact on pre-service EFL teachers' preparedness for teaching. IAFOR Journal of Education, 9(2), 111-126.

S6: Özkanal, Ü., Yüksel, İ., \& Uysal, B. Ç. B. (2020). The pre-service teachers' reflection-onaction during distance practicum: a critical view on EBA TV English courses. Eğitimde Nitel Araştırmalar Dergisi, 8(4), 1347-1364.

S7: Yüksel, İ., \& Uysal, B. C. B. (2021). Foreign language education through online communities of practice. In C. H. Xiang (Ed.), Trends and Developments for the Future of Language Education in Higher Education (pp. 141-165). IGI Global.

For reliability and validity concerns, we have explained the selection process in a detailed way 
so that it would be the same if any other researchers repeat the same search criteria. Another measure taken for validity and reliability is the exclusion of one to two studies that focused on pre-service EFL teachers together with other departments' student-teachers. We omitted such studies because data in them were analysed mixed with the ones from student-teachers of other departments. On the other hand, S3 was included because it analyzed and presented the data gathered from EFL and pre-school student teachers separately, so it was easy to follow the findings based only on EFL pre-service teachers on the topic in question.

\section{Data Analysis}

After completing the first three steps in accordance with Arksey and O'Malley's (2005) model, the fourth step, namely plotting the data, was realized via marking the articles for the following three categories of criteria, as in Table 1 . The first and the second categories in Table 1 were summarized in terms of descriptive statistics $(f$ and percentage values), while the third category was thematically analyzed for a summary of findings, all of which together constitute the final step of the scoping review framework.

Table 1. Coding criteria*

\begin{tabular}{lll}
\hline 1. Bibliography & Criterion & Accepted Value \\
\hline & Author(s) & Any \\
\hline & Published year & $\begin{array}{l}\text { During the COVID-19 } \\
\text { Pandemic (March 2020- } \\
\text { September 2021) }\end{array}$ \\
\hline & Title & Any \\
\hline & Category of \\
publication & $\begin{array}{l}\text { Journal Article, Book } \\
\text { Chapter, Theses and } \\
\text { Dissertations }\end{array}$ \\
\hline & Language & Turkish and/or English \\
\hline 2. Research Design & Type of study & Empirical, Non-Empirical \\
\hline Setting & Practicum \\
\hline & Participants & Turkish Pre-Service EFL \\
& Teachers \\
\hline Data analysis & Any \\
\hline Focus & Instrument & Any \\
\hline Aim & Any \\
\hline
\end{tabular}

*(adapted from Selvi, 2021)

For reliability concerns, studies that met the criteria displayed were coded separately by both of us, first; overall inter-rater reliability was $94 \%$. Then, we held numerous online meetings to elaborate on and arrive at a consensus about the findings of the present study for sustaining reliability.

\section{Findings}

The research question is analyzed in three layers, (a) bibliography, (b) research design, and (c) focus of the studies.

\section{Bibliography}

When bibliographic features of the studies are considered, Derin Atay of Bahçeşehir University (BAU), İlknur Yüksel and Banu Çiçek Başaran Uysal from Osmangazi University (OGU) have become the most publishing scholars with two articles each. Other scholars, Feride Gök Çolak and Gülümser Efeoğlu from Yıldız Teknik University, Saadet Korucu-Kış from Necmettin Erbakan University, Gülten Koşar from Mustafa Kemal University, Enisa Mede from BAU, and Ümit Özkanal from OGU published once on the topic in question. Three $(42.85 \%)$ out of seven published studies were published in 2020; rest ( $\mathrm{f}=4,57,14 \%)$ in 2021.

Other than S7 which is a book chapter, all are peer-reviewed articles ( $f=6,85,71 \%)$. Except for S3 and S6, all five were published in international academic platforms such as Taylor \& Francis, Springer and ERIC databases. Naturally, earlier published studies received more citations than the others. For example, S2 was cited 19 times; S6 seven times; both published in 2020. While S3 and S7 were receiving no citations, S4 was mentioned once; S1 three and S5 four times. S3 is an exception in this matter; it was published in 2020 but has not received any citation, yet. This might be due to the fact that it was the only study published in Turkish language.

\section{Research Design}

This paper also focuses on analyzing studies in terms of their methodological orientations. When Table 1 is considered, the second part deals with the research design, setting, and instrument. All the studies in question are empirical ones where they collected data from EFL pre-service teachers studying in Turkey and registered at practicum 
courses. Data were collected qualitatively in all and analyzed via qualitative methods, though sub categories were various. S3 chose phenomenography $(14.28 \%) ;$ S4, action research (14.28\%), S5, S6 and S7, case studies (42.85\%). S1 and S2 $(28.57 \%)$ cited no specific category other than being qualitative research. As for research design, setting, and instrumentation, Table 2 below outlines the general picture.

\section{Table 2. Research design}

\begin{tabular}{|c|c|c|c|}
\hline & Design & Setting & Instrument \\
\hline S1 & Qualitative & $\begin{array}{l}\text { School } \\
\text { Experience } \\
\text { (Pandemic Phase } \\
\text { 1) }\end{array}$ & Focus group interview \\
\hline S2 & Qualitative & $\begin{array}{l}\text { Teaching Practice } \\
\text { (Pandemic Phase } \\
\text { 1) }\end{array}$ & $\begin{array}{l}\text { E-mentoring discussion, } \\
\text { focus group interview }\end{array}$ \\
\hline S3 & $\begin{array}{l}\text { Qualitative- } \\
\text { Phenomenography }\end{array}$ & $\begin{array}{l}\text { Teaching Practice } \\
\text { (Pandemic Phase } \\
\text { 3) }\end{array}$ & Interview \\
\hline S4 & $\begin{array}{l}\text { Qualitative-Action } \\
\text { research }\end{array}$ & $\begin{array}{l}\text { School Experience } \\
\text { (Pandemic Phase } \\
\text { 2) }\end{array}$ & $\begin{array}{l}\text { Online discussion post, } \\
\text { reflective journal, focus } \\
\text { group interview }\end{array}$ \\
\hline S5 & $\begin{array}{l}\text { Qualitative-Case } \\
\text { study }\end{array}$ & $\begin{array}{l}\text { Teaching Practice } \\
\text { (Pandemic Phase } \\
\text { 1) }\end{array}$ & $\begin{array}{l}\text { Questionnaire with open- } \\
\text { ended items }\end{array}$ \\
\hline S6 & $\begin{array}{l}\text { Qualitative-Case } \\
\text { study }\end{array}$ & $\begin{array}{l}\text { Teaching Practice } \\
\text { (Pandemic Phase } \\
\text { 1) }\end{array}$ & Reflective journal \\
\hline S7 & $\begin{array}{l}\text { Qualitative-Case } \\
\text { study }\end{array}$ & $\begin{array}{l}\text { School Experience } \\
\text { (Pandemic Phase } \\
\text { 2) }\end{array}$ & eReflective journal \\
\hline
\end{tabular}

For setting, all the studies were conducted in ELT Departments at Turkish universities with EFL pre-service teachers. However, time and the course of the practicum varies. S1, S4 and S7 $(42.85 \%)$ conducted their studies in the first phase of practicum, i.e., School Experience where studentteachers perform classroom observations and prepare reflective reports. S2, S3, S5 and S6 (57.14\%) preferred to work during the second phase, Teaching Practice.

Three fully-online academic semesters have been spent so far since the beginning of the COVID-19 pandemic in Turkey. Parallel with this, we categorized the setting for duration into three phases all of which were conducted completely online accordingly. First phase (i.e., Pandemic Phase 1 according to Table 2) began when the pandemic started in March 2020, and extended till mid-June 2020, when the semester ended. It is a spring term in Turkey and pre-service teachers had already registered for the Teaching Practice course of the practicum process. Second phase (i.e., Pandemic Phase 2) started September 2020 and ended by mid-January 2021, which constitutes the fall semester. Then, student teachers took the School Observation course. Final phase (i.e., Pandemic Phase 3) starting from February 2021 and ending by mid-June 2021 is just like Pandemic Phase 1. Although first and the third phases look the same at first glance, in terms of policies and practices, they vary. While in the first phase school placements were not allowed and cancelled, in the third phase this was done via online platforms like Zoom application. When the studies at Table 2 are analyzed, most of them ( $\mathrm{f}=4,57.14 \%)$ were conducted during the Pandemic Phase 1 (S1, S2, S5 and S6). It is observed that $S 4$ and S7 were done in Pandemic Phase 2. Only S3 was performed during Pandemic Phase 3.

As for data collection tools, most of the studies $(\mathrm{f}=4,57.14 \%)$ utilized interview protocols; among them, S1, S2 and S4 preferred focus group form. S4, S6 and S7 employed the reflective journals; S2 mentoring discussions, $\mathrm{S} 4$ online discussion posts and S5 an open-ended questionnaire. When the studies were examined, findings were mostly reported qualitatively together with participants' verbal responses. Beside this, while S3 and S6 picturized the themes emerged out of data analysis, S7 preferred to present them with descriptive statistics as well as participant artefacts. Similarly, S4 preferred to display all themes in a holistic table.

\section{Focus}

Focus is analyzed in terms of aims and findings of the scoped studies. In Table 3, all studies analyzed concentrated on eliciting pre-service teacher views, and verbs used for the indication of the aim such as explore, find out, examine, and discover clearly pinpoint that. Despite the variation in instrumentation, the overall aim of those researchers is how to make the practicum period beneficial as possible for all the actors involved. 
Table 3. Focus

\begin{tabular}{ll}
\hline Study \# & Objective(s) \\
\hline S2 & $\begin{array}{l}\text { to uncover the different components of online } \\
\text { mentoring as perceived and expected by the pre-service } \\
\text { teachers. }\end{array}$ \\
\hline S3 & $\begin{array}{l}\text { to explore the e-practicum and e-mentoring from the } \\
\text { perspectives of the pre-service teachers. }\end{array}$ \\
& $\begin{array}{l}\text { to do needs-analysis in line with the pre-service } \\
\text { teachers' views on both positive and challenging } \\
\text { aspects of the online practicum course. }\end{array}$ \\
\hline S4 & $\begin{array}{l}\text { to find out whether experiencing critical incidents } \\
\text { vicariously offer meaningful contributions to remote } \\
\text { practicum from student teachers' viewpoint. }\end{array}$ \\
\hline S5 & $\begin{array}{l}\text { to explore pre-service English-as-a-foreign-language } \\
\text { teachers' conceptions of the influence of distance } \\
\text { teaching practice on their preparedness for the first } \\
\text { year of teaching. }\end{array}$ \\
\hline S6 & $\begin{array}{l}\text { to examine the pre-service teachers' reflections on the } \\
\text { action of experienced teachers teaching English } \\
\text { through broadcasting; the EBA TV. }\end{array}$ \\
\hline S7 & $\begin{array}{l}\text { to discover the challenges of online language teaching } \\
\text { and to present practical tasks to address them by } \\
\text { examining the reflections of prospective teachers. }\end{array}$ \\
\hline
\end{tabular}

For findings, various fruitful results were documented. Divided into two separate tables as positive/beneficial and negative/challenging aspects, Table 4 and 5 clearly demonstrate the outcomes of the seven studies, respectively. Those tables include some of the direct phrases and sentences from the relevant scoped studies in order to reflect the authors' own perspectives accurately. Some of the studies focused on the participants' observed perception of online education while some others had implementations. No matter what the method or intervention is, outcomes of those studies lead into the perception of positive/beneficial or negative/challenging aspects with regard to distance education practicum contexts caused by the pandemic.

According to Table 5, aiming at the components of online mentoring, S1 found that pre-service teachers expected more time and attention from their mentors and more classroom management topics from their supervisors. In Table 4, S2 documented that e-practicum is feasible and advantageous in experiencing digital integration into teacher education. S3 proved that e-practicum course can be advantageous especially for theoretical components since pre-service teachers felt more comfortable in participating, and they also witnessed how mentors dealt with problems during online education and how lessons could be successful if the academic level of the students was good. Those pre-service teachers were content with perceiving the emergence of many digital tools that ease the task of the teachers. S3 also touched upon the difficulties arisen for the practicum such as classroom management, time constraints, and digital illiteracy of teachers in Table 5. However, the most important drawback of that online application might be the fact that preservice teachers graduated without practicing the feeling of a real classroom atmosphere.

S4 is one of the studies with an implementation, i.e. Critical Incidents (CI), and pre-service teachers benefitted from action plan immensely in receiving a real-life like experience, observing multiple perspectives, increasing their content and pedagogical knowledge, and as a result they felt more confident in designing activities and solving problems according to Table 4. Participants also stated that the experience could be better if some changes were applied on group size, technical problems and the content of CIs. Focusing on preservice teachers' conceptions on how ready they are for the first-year teaching, S5 showed that practicum could not be replaced with paperwork, and lack of school placement led to problems in professional self-confidence. Interactions among the pre-service teachers, mentors and supervisors were also problematic during the Distant Teaching Practice, which, in turn, disappointed prospective teachers.

S6 required pre-service teachers to observe classes broadcasted on EBA TV, which yielded both best practices and problems. Participants labeled the effective use of body language and realia together with the inclusion of many activities as best practices. Nevertheless, they pinpointed the problems with the materials and expected the activities to be more varied and engaging. Teachers' pronunciation and use of advanced language is another challenge stated by them. In addition, short lessons, distractions for students and classroom management problems are what made the process difficult. The last study analyzed, S7, included pre-service teachers in Communities of Practice (CoP) which led an opportunity for shaping professional identities since they both attended live classes to observe and even taught a few hours. They perceived the challenges of online teaching under five headings: classroom 
management, lack of a dedicated space for forward some solutions to the observed issues is learning, lack of interaction, distractions, and what made the study meaningful for those pretechnological problems. However, putting service teachers.

Table 4. Positive/Beneficial aspects

\begin{tabular}{|c|c|c|c|c|}
\hline S2 & S3 & $\mathrm{S} 4$ & S6 & S7 \\
\hline $\begin{array}{l}\text { - the feasibility of the } \\
\text { e-practicum, } \\
\text { - pre-service teachers' } \\
\text { ability to overcome } \\
\text { technical problems } \\
\text { with abundant online } \\
\text { teaching experience, } \\
\text { - the advantages of } \\
\text { digital integration. }\end{array}$ & $\begin{array}{l}\text { - they felt more } \\
\text { comfortable in } \\
\text { speaking during online } \\
\text { lessons, } \\
\text { - they observed how } \\
\text { mentors solved the } \\
\text { problems while } \\
\text { teaching online, } \\
\text { - they perceived if the } \\
\text { level of the students is } \\
\text { good, the online lesson } \\
\text { flows smoothly, } \\
\text { - many digital tools } \\
\text { emerged due to } \\
\text { COVID-19 and they } \\
\text { started to learn } \\
\text { creating an online } \\
\text { content. }\end{array}$ & $\begin{array}{l}\text { - by presenting CI through Kolb's } \\
\text { experiential learning cycle via a } \\
\text { ecollaborative virtual application, both } \\
\text { the CIs and Google Docs-mediated } \\
\text { activities offered student teachers real- } \\
\text { life like experiences, } \\
\text { - exchange of ideas made them aware } \\
\text { of multiple perspectives and helped } \\
\text { them develop shared understandings } \\
\text { and a sense of learning community, } \\
\text { - dealing with CIs led to improvements } \\
\text { in participants' pedagogic content } \\
\text { knowledge, } \\
\text { - they felt more confident and } \\
\text { proficient to come up with purposeful } \\
\text { activities and relevant solutions. }\end{array}$ & $\begin{array}{l}\text {-on EBA TV, } \\
\text { teachers use body } \\
\text { language } \\
\text { effectively, } \\
\text { - using realia } \\
\text { during distance } \\
\text { education is } \\
\text { motivating and } \\
\text { attractive, } \\
\text { - including many } \\
\text { activities (more } \\
\text { than three) is a } \\
\text { good way to } \\
\text { reinforce learning. }\end{array}$ & $\begin{array}{l}\text { - through forming an online } \\
\text { CoP for practicum, pre- } \\
\text { service teachers attended the } \\
\text { live classes over video- } \\
\text { conferencing tools, } \\
\text { - opportunity to observe } \\
\text { learner and teacher } \\
\text { behaviors, } \\
\text { - had a chance to teach a few } \\
\text { hours throughout the term, } \\
\text { - re-shaped professional } \\
\text { identities, } \\
\text { - gained better } \\
\text { understanding of the } \\
\text { challenges of online } \\
\text { teaching, } \\
\text { - presented practical tasks to } \\
\text { address the challenges. }\end{array}$ \\
\hline
\end{tabular}


Table 5. Negative/Challenging aspects

\begin{tabular}{|c|c|c|c|c|c|}
\hline S1 & S3 & S4 & S5 & S6 & S7 \\
\hline $\begin{array}{l}\text { - pre-service } \\
\text { teachers } \\
\text { expected more } \\
\text { time and } \\
\text { attention from } \\
\text { the mentors, } \\
\text { - expected } \\
\text { supervisors to } \\
\text { sustain } \\
\text { continuous } \\
\text { communication } \\
\text { between } \\
\text { coordinators and } \\
\text { mentors, } \\
\text { - expected } \\
\text { supervisors to } \\
\text { provide more } \\
\text { online practice } \\
\text { opportunities, } \\
\text { especially on } \\
\text { student } \\
\text { engagement in } \\
\text { online classes or } \\
\text { virtual classroom } \\
\text { management. }\end{array}$ & $\begin{array}{l}\text { - some } \\
\text { teachers lack } \\
\text { the } \\
\text { necessary } \\
\text { digital } \\
\text { literacy, } \\
\text { - some parts } \\
\text { of skipped } \\
\text { due to time } \\
\text { constraints, } \\
\text { - controlling } \\
\text { the students } \\
\text { can be } \\
\text { problematic, } \\
\text { - graduation } \\
\text { without } \\
\text { experiencing } \\
\text { the real } \\
\text { classroom } \\
\text { atmosphere. }\end{array}$ & $\begin{array}{l}\text { - group } \\
\text { size, } \\
\text { - technical } \\
\text { issues, } \\
\text { - the } \\
\text { scope of } \\
\text { CIs }\end{array}$ & $\begin{array}{l}\text { - doing only } \\
\text { paperwork did not } \\
\text { result in } \\
\text { broadening } \\
\text { pedagogical } \\
\text { content } \\
\text { knowledge and } \\
\text { transferring it into } \\
\text { practice, } \\
\text { - lack of teaching } \\
\text { experience, the } \\
\text { opportunity to } \\
\text { observe the } \\
\text { classroom } \\
\text { practices of } \\
\text { mentor teachers, } \\
\text { and the operation } \\
\text { of schools, } \\
\text { - lack of self- } \\
\text { confidence in } \\
\text { current teaching } \\
\text { abilities, } \\
\text { - lack of } \\
\text { interaction } \\
\text { between pre- } \\
\text { service teachers } \\
\text { and mentors, and } \\
\text { also university } \\
\text { supervisors. }\end{array}$ & $\begin{array}{l}\text { - materials could have } \\
\text { been more colorful and } \\
\text { engaging for the students } \\
\text { on EBA TV, } \\
\text { - activities were not } \\
\text { varied and appropriate } \\
\text { to the learners' level, } \\
\text { - pronunciation of the } \\
\text { observed teacher was } \\
\text { problematic, } \\
\text { - teachers' use of } \\
\text { advanced language items } \\
\text { and structures could be } \\
\text { demotivating and } \\
\text { discouraging for the } \\
\text { students, } \\
\text { - } 20 \text { minutes is not } \\
\text { enough to cover the topic } \\
\text { and the tasks, } \\
\text { - learners may be easily } \\
\text { distracted due to } \\
\text { distance education, } \\
\text {-it may be difficult to } \\
\text { manage the lesson and } \\
\text { motivate the learners, } \\
\text { - without teacher } \\
\text { feedback, it becomes } \\
\text { more challenging for } \\
\text { learners to fulfill the } \\
\text { learning goals. }\end{array}$ & $\begin{array}{l}\text { - classroom management: off- } \\
\text { task learners or communication } \\
\text { breakdowns, } \\
\text { - lack of a dedicated space for } \\
\text { learning: not being in a } \\
\text { classroom-like learning } \\
\text { environment deprives teachers of } \\
\text { the feedback that they receive by } \\
\text { observing the learners' body } \\
\text { language and participation rate } \\
\text { of learners in class. } \\
\text { - lack of interaction: learners } \\
\text { were negatively influenced with } \\
\text { regards to socio-emotional } \\
\text { development, target language } \\
\text { improvement, and motivation, } \\
\text { - distractions: pupils had } \\
\text { difficulty in focusing on English } \\
\text { lessons since they were on } \\
\text { computers and there were many } \\
\text { distractors (online games, other } \\
\text { communication applications, } \\
\text { watching videos, external factors } \\
\text { such as children, mothers, or } \\
\text { siblings), } \\
\text { - technological problems: lack of } \\
\text { required hardware (computer, } \\
\text { microphone, camera) and a } \\
\text { stable internet connection, } \\
\text { sharing a computer with siblings, } \\
\text { teachers' digital illiteracy }\end{array}$ \\
\hline
\end{tabular}

\section{Discussion and Conclusion}

Online learning has been planned to be integrated into teacher education for the last two decades globally (Enochsson \& Rizza, 2009; European Commission, 2007). Because as also highlighted by Darling-Hammond (2000), teacher education greatly contributes to teacher competencies including digital literacy skills. However, a recent report published by OECD (2015) declares that the policies and practices still have not been there yet to sustain good ICT pedagogies due to overestimation of teachers' and students' digital skills as well as poor quality of software and courseware. Teachers being a key agent in such a transformation, teacher education programs have a significant role in developing ICT competence to equip student teachers to meet the curriculum demands of public education. COVID-19 has played a crucial role in accelerating and achieving this necessity, if ever, due to a quick adoption and adaptation to online teaching in tertiary education as well. Previously, it was already found that EFL student teachers were confident in their basic digital skills but lacked didactic ICT competence and heavily relied on their teacher educators as their role models in the Norwegian context (Røkenes \& Krumsvik, 2016).

The present study reached similar conclusions in that EFL pre-service teachers heavily depended on their teacher educators during the pandemic era for practicum courses (S1, S2 and S6) particularly when the school placements were cancelled and exchanged with other practice and/or non-practice tasks like in S5 during Pandemic Phase 1. Likewise, studies conducted in different countries on online practicum applications during the pandemic display a variety of strategies to compensate for the face-to-face practicum. In Egypt, in Badawi's study (2021) instead of school visits, the micro-teaching practices of EFL preservice teachers where student teachers were assigned to watch, analyze and reflect upon the previously recorded actual face-to-face classes are similar to S6's. Later, student teachers were to 
imitate the video content and upload their own simulated videos to YouTube to receive feedback from their university supervisors on behalf of the real-time mentors whom they were never assigned the task with, since the real practicum procedures were cancelled by the university due to pandemic. Student teachers reported a discontent with the application since no real instructional skills such as classroom management and error correction strategies were employed in hypothetical simulations, which shows a great resemblance with S5 where school placement was never realized. Another similar approach was conducted in Greece where student teachers simulated their lesson plans on online platforms to their peers (Brinia \& Psoni, 2021) as it is in S1 and S2. This simulation contributed to participants in experiencing a new teaching form and developing insights on potential problems.

Once the online practicum processes started during Pandemic Phase 2 and 3, pre-service teachers started to highlight the significance of participating online classes for either observation or practice teaching with critical evaluations (S3, S4, S6 and S7). As a result of this, gaining a new form of teaching and experiencing challenging opportunities to develop novel skills were reported as the positive outcomes. As it was applied in S3 and S7, and also in some other countries (USA, Indonesia, Chile and Portugal are a few examples), regular practicum norms were carried onto online platforms, where pre-service teachers continued teaching an actual class via Zoom, Google Classroom, and such applications, and they were assigned a mentor to collaborate with.

Researchers from each country highlight challenges that occurred and hindered participants' development. For example, Varela and Desiderio (2020) indicated a perception of unaccomplishment since the teacher candidates had been prepared for face-to-face teaching until the COVID-19 outbreak, which also negatively affected their job aspirations. Shinta and Aprilia (2020) confirm these challenges with a study of a group of Indonesian EFL pre-service teachers describing classroom management and assessment as the most problematic areas. Assunção Flores and Gago (2020) emphasize the constraint of internet accessibility and its negative effects on pre-service teachers during the practicum. These studies show that both personal teaching competency and social development of student teachers have negatively been affected. However, participants in those studies stated that it provided an opportunity for adapting themselves to unexpected situations, fostered reflection about finding solutions to emerging specific problems that they had not been trained for. Reflective thinking and practice for self and others' teaching as was realized in S7 and S6, respectively, seems to be an opportunity for critically reviewing professional actions, beliefs and attitudes, which can be realized by using a variety of reflective tools (Tuncer \& Özkan, 2021). Particularly on online platforms, reflective tools are the best for reflecting upon the performance which was believed that epracticum provided such an opportunity to the pre-service EFL teachers in all the scoped studies except for S5.

Outcomes of the relevant literature are compatible with what was found in the scoped studies. Having both positive and negative perceptions about e-practicum, pre-service teachers also perceived e-mentoring a unique experience for their future career. Yet, a warning comes from Sepulveda-Escobar and Morrison (2020) in that without the right preparations for online practicum procedures, there might be detrimental side effects on student teachers' future professional motivation, for which S7 highlights the significance of socio-emotional well-being. Feeling isolated and staying in front of a screen for a long time with very limited access to others' real existence, socio-emotional competence and mindfulness have become important in surviving during the pandemic. Relevant literature on teacher well-beingness (Hadar et al., 2020; Li et al., 2020; Schonert-Reichl, 2017; Talidong \& Toquero, 2020) necessitates teacher education programs to prioritize inclusion and improvement of the socioemotional competence. As teaching itself being already a very stressful job, many scholars suggested alternative back-ups for dealing with 
the problems emerged during pandemic (Gałązka, \& Jarosz, 2021; MacIntyre et al., 2020; Matiz et al., 2020), which is another outcome of this study in that pre-service teachers' well-beingness should also be considered during online teaching.

For conclusions, this scoping review, though limited to only the COVID-19 pandemic, yielded beneficial outcomes in that the studies analyzed displayed various suggestions for further similar emergency times and/or new normal norms. They showed alternative practical pathways for the institutions to replace face-to-face procedures. For example, as it was implemented in S1 and S2, peerto-peer teaching groups can be formed, which can be integrated with reflection-on-action and $\mathrm{CI}$ analyses as in S4 and S6. If possible, such schemes can be adopted with appropriate infrastructure and measures taken to sustain a fruitful learning experience for all parties as practiced in S7. Despite these outcomes, more studies need to be conducted to analyze online practicum communities. For achieving this, graduate and postgraduate studies are valuable windows of opportunities, and supervisors might lead their students to work on such issues. Another suggestion that might be deduced is to prioritize, integrate and facilitate socio-emotional competence into EFL teacher education curricula. Last but not least, a final suggestion would be extending what's learned from online practicum experience during pandemic and incorporate it into face-to-face and hybrid settings, where necessary and possible.

One important limitation of the study is caused by the chosen time period spent within the COVID-19 pandemic. As a result, very few studies were found to be used in the scoping review. On the other hand, such emerging studies are very valuable in that they are the pioneers and serve for the basis of the forthcoming practices and studies. Thus, this scoping review hopes to build a foundation and give valuable insights to the practitioners and researchers for improving the existing conditions in the field of EFL pre-service teaching practicum.

\section{References}

Ali, W. (2020). Online and remote learning in higher education institutes: A necessity in light of COVID-19 pandemic. Higher Education Studies, 10(3), 16-25. https://doi.org/10.5539/hes.v10n3p16.

Allen, J. M., \& Wright, S. E. (2014). Integrating theory and practice in the pre-service teacher education practicum. Teachers and Teaching, 20(2),

136-151. https://doi.org/10.1080/13540602.2013.848568

Anderson, L. M., \& Stillman, J. A. (2013). Student teaching's contribution to preservice teacher development: A review of research focused on the preparation of teachers for urban and high-needs contexts. Review of Educational Research, 83(1), 3-69. https://doi.org/10.3102\%2F0034654312468619

Arksey, H., \& O'Malley, L. (2005). Scoping studies: Towards a methodological framework. International Journal of Social Research Methodology, 8(1), 19-32. https://doi.org/10.3102\%2F0034654312468619

Assunção Flores, M., \& Gago, M. (2020). Teacher education in times of COVID-19 pandemic in Portugal: National, institutional and pedagogical responses. Journal of Education for Teaching, 46(4), 507-516. https://doi.org/10.1080/1364557032000119616

Badawi, M. F. A. (2021). The effect of e-practicum on developing EFL student teachers' instructional performance and e-teaching self-efficacy, بحوثفتتريساللغات 2(16), 685-727. https://dx.doi.org/10.21608/ssl.2021.71053.10 66.

Bahcivan, E., Gurer, M. D., Yavuzalp, N., \& Akayoglu, S. (2019). Investigating the relations among pre-service teachers' teaching/learning beliefs and educational technology integration competencies: A structural equation modeling study. Journal of Science Education and Technology, 28(5), 579588. https://doi.org/10.1007/s10956-01909788-6.

Başaran Uysal, B. Ç., \& Savaş, P. (2021). Overview of the challenges of practicum practices in English language teaching in Turkey: A meta synthesis study on literature between 2004 and 2019. Inonu University Journal of the 
Faculty of Education, 22(2), 1669-1712. https://doi.org/10.17679/inuefd.886731.

Brinia, V., \& Psoni, P. (2021). Online teaching practicum during COVID-19: The case of a teacher education program in Greece. Journal of Applied Research in Higher Education. https://doi/10.1108/JARHE-07-2020-0223/.

Brown, A. L. (2014). Implementing active learning in an online teacher education course. American Journal of Distance Education, 28(3), 170-182. https://doi.org/10.1080/08923647.2014.924695

Corcoran, E. (1981). Transition shock: The beginning teacher's paradox. Journal of Teacher Education, 32(3), 19-23. https://doi.org/10.1177\%2F0022487181032003 04.

Darling-Hammond, L. (2000). How teacher education matters. Journal of Teacher Education, 51(3), 166-173.

https://doi.org/10.1177\%2F0022487100051003 002.

Darling-Hammond, L. (2017). Teacher education around the world: What can we learn from international practice?. European Journal of Teacher Education, 40(3), 291-309. https://doi.org/10.1080/02619768.2017.131539 9.

Enochsson, A., \& Rizza, C. (2009). ICT in Initial Teacher Training: Research Review (OECD Education Working Papers No. 38). OECD Publishing. https://doi.org/10.1787/220502872611.

Ersin, P., \& Atay, D. (2021). Exploring online mentoring with preservice teachers in a pandemic and the need to deliver quality education. International Journal of Mentoring and Coaching in Education,10(2), 203-215. https://doi.org/10.1108/IJMCE-11-2020-0077.

Ersin, P., Atay, D., \& Mede, A. (2020). Boosting preservice teachers' competence and online teaching readiness through e-practicum during Covid-19 outbreak. International Journal of TESOL Studies, 2(2), 112-124. https://doi.org/10.46451/ijts.2020.09.09.

European Commission. (2007). Key competences for lifelong learning. European reference framework. Retrieved October 1, 2021 from https:/op.europa.eu/en/publication-detail//publication/5719a044-b659-46de-b58b$606 b c 5 b 084 c 1$.
Ewing, R., \& Smith, D. (2003). Retaining quality beginning teachers in the profession. English Teaching: Practice and Critique, 2(1), 15-32.

Farrell, T. S. C. (2008). Promoting reflective practice in initial English language teacher education: Reflective microteaching. Asian Journal of English Language Teaching, 18, 1-15.

Feiman-Nemser, S. (2001). From preparation to practice: Designing a continuum to strengthen and sustain teaching. Teachers College Record, 103(6), 1013-55.

Forbes, D., \& Khoo, E. (2015). Voice over distance: A case of podcasting for learning in online teacher education. Distance Education, 36(3), 335-350.

Gałązka, A., \& Jarosz, J. (2021). The role of educational coaching in enhancing teachers' well-being during pandemic. Retrieved September 23, 2021 from https://rebus.us.edu.pl/bitstream/20.500.12128/2 1737/1/Galazka_The_role_of_educational_coachi ng_in_enhancing_teachers_wellbeing_during_pandemic.pdf.

Gillies, D. (2008). Student perspectives on videoconferencing in teacher education at a distance. Distance Education, 29(1), 107-118. https://doi.org/10.1080/01587910802004878.

Gold, Y. (1996). Beginning teachers: Attrition, mentoring and induction. In J. Sikula, T. Buttery \& E. Guyton (Eds.), Handbook of research on teacher education (p.548-593). Simon \& Schuster.

Gök Çolak, F., \& Efeoğlu, G. (2020). Yeni normalleşme sürecinde öğretmenlik uygulaması dersine yönelik ihtiyaç analizi: SWOT analizi örneği. Kesit Akademi Dergisi, 7(27), 176-197.

Hadar, L. L., Ergas, O., Alpert, B., \& Ariav, T. (2020). Rethinking teacher education in a VUCA world: student teachers' social-emotional competencies during the Covid-19 crisis. European Journal of Teacher Education, 43(4), 573-586.

Huang, J. (2020). Successes and challenges: Online teaching and learning of Chemistry in higher education in China in the time of COVID19. Journal of Chemical Education, 97(9), 28102814.

https://doi.org/10.1021/acs.jchemed.0c00671. 
Huber, S. G., \& Helm, C. (2020). COVID-19 and schooling: Evaluation, assessment and accountability in times of crises-reacting quickly to explore key issues for policy, practice and research with the school barometer. Educational Assessment, Evaluation and Accountability, 32(2), 237-270. https://doi.org/10.1007/s11092-020-09322-y.

Judd, J., Rember, B. A., Pellegrini, T., Ludlow, B., \& Meisner, J. (2020). This is not teaching: The effects of COVID-19 on teachers. https://www.socialpublishersfoundation. org/knowledge_base/this-is-not-teachingtheeffects-of-covid-19-on-teachers.

Kane, R. G., Mallon, M., \& Butler, P. J. (2006). Perceptions of teachers and teaching. New Zealand Ministry of Education. Retrieved September 14, 2021 from https://ndhadeliver.natlib.govt.nz/delivery/Deliv eryManagerServlet?dps_pid=IE758702.

Karataş, T. Ö., \& Tuncer, H. (2020). Sustaining language skills development of pre-service EFL teachers despite the COVID-19 interruption: A case of emergency distance education. Sustainability, 12(19),8188. https://doi.org/10.3390/su12198188.

Kibar, E. P., \& Ozer, Z. (2020). Investigating preservice EFL teachers' perceptions of online education: Research article. FIRE: Futuristic Implementations of Research in Education, 1(2), 90-95.

http://www.firejournal.org/index.php/fire/article/ view/28.

Korucu-K1ş, S. (2021). Preparing student teachers for real classrooms through virtual vicarious experiences of critical incidents during remote practicum: A meaningfulexperiential learning perspective. Education and Information Technologies, 26, 6949-6971. https://doi.org/10.1007/s10639-021-10555-7.

Koşar, G. (2021). Distance teaching practicum: Its impact on pre-service EFL teachers' preparedness for teaching. IAFOR Journal of Education, 9(2), 111-126. https://doi.org/10.22492/ije.9.2.07.

König, J., Jäger-Biela, D. J., \& Glutsch, N. (2020). Adapting to online teaching during COVID19 school closure: Teacher education and teacher competence effects among early career teachers in Germany. European Journal of Teacher Education, 43(4), 608-622. https://doi.org/10.1080/02619768.2020.180965 0 .

Li, Q., Miao, Y., Zeng, X., Tarimo, C. S., Wu, C., \& Wu, J. (2020). Prevalence and factors for anxiety during the coronavirus disease 2019 (COVID-19) epidemic among the teachers in China. Journal of Affective Disorders, 277, 153158. https://doi.org/10.1016/j.jad.2020.08.017.

MacIntyre, P. D., Gregersen, T., \& Mercer, S. (2020). Language teachers' coping strategies during the Covid-19 conversion to online teaching: Correlations with stress, wellbeing and negative emotions. System, 94, 102352. https://doi.org/10.1016/j.system.2020.102352.

Matiz, A., Fabbro, F., Paschetto, A., Cantone, D., Paolone, A. R., \& Crescentini, C. (2020). Positive impact of mindfulness meditation on mental health of female teachers during the COVID-19 outbreak in Italy. International Journal of Environmental Research and Public Health, 17(18),

1-22. https://doi.org/10.3390/ijerph17186450.

Mishra, L., Gupta, T., \& Shree, A. (2020). Online teaching-learning in higher education during lockdown period of COVID-19 pandemic. International Journal of Educational Research Open, 1, 100012. https://doi.org/10.1016/j.ijedro.2020.100012.

OECD. (2015). Students, computers and learning: Making the connection. OECD Publishing. https://doi.org/10.1787/9789264239555-en.

Özkanal, Ü., Yüksel, İ., \& Uysal, B. Ç. B. (2020). The pre-service teachers' reflection-on-action during distance practicum: A critical view on EBA TV English courses. Eğitimde Nitel Araştırmalar Dergisi, 8(4), 1347-1364. https://doi.org/10.14689/issn.21482624.8c.4s.12m.

Paudel, P. (2021). Online education: Benefits, challenges and strategies during and after COVID-19 in higher education. International Journal on Studies in Education,3(2), 70-85. https://doi.org/10.46328/ijonse.32.

Røkenes, F. M., \& Krumsvik, R. J. (2016). Prepared to teach ESL with ICT? A study of digital competence in Norwegian teacher education. Computers $\mathcal{E}$ Education, 97, 1-20. https://doi.org/10.1016/j.compedu.2016.02.01 4.

Schonert-Reichl, K. A. (2017). Social and emotional learning and teachers. The Future of Children, 
$27(1)$

137-155

http://www.jstor.org/stable/44219018.

Seferoğlu, G. (2006). Teacher candidates' reflections on some components of a pre-service English teacher education programme in Turkey. Journal of Education for Teaching, 32, 369-378. https://doi.org/10.1080/02607470600981953

Selvi, A. F. (2021). A scoping review of the "NEST/NNEST studies" in Turkey: A country in focus. Bolu Abant İzet Baysal University Journal of Faculty of Education, 21(1), 54-73.

https://dx.doi.org/10.17240/aibuefd.2021.21.6 0703-780084.

Sepulveda-Escobar, P., \& Morrison, A. (2020). Online teaching placement during the COVID-19 pandemic in Chile: Challenges and opportunities. European Journal of Teacher Education, 43(4), 587-607. https://doi.org/10.1080/02619768.2020.182098 1.

Shinta, L. G. B., \& Aprilia, N. (2020). EFL pre-service teachers' perceptions of online teachingpracticum during COVID-19 Pandemic. JELLiT (Journal of English Language, Literature, and Teaching), 4(2), 58-66.

Smith, K., \& Lev-Ari, L. (2005). The place of the practicum in pre-service teacher education: The voice of the students. Asia-Pacific Journal of Teacher Education, 33(3), 289-302. https://doi.org/10.1080/13598660500286333.

Talidong, K. J. B., \& Toquero, C. M. D. (2020). Philippine teachers' practices to deal with anxiety amid COVID-19. Journal of Loss and Trauma, 25(6-7),

573-579. https://doi.org/10.1080/15325024.2020.175922 5.

Tuncer, H., \& Özkan, Y. (2021). Reflective tools in an English Language Teaching context: Contributions, challenges and recommendations. Kahramanmaraş Sütçü İmam Üniversitesi Sosyal Bilimler Dergisi, 18(1), 181-204.

https://doi.org/10.33437/ksusbd.671482

Tülüce, H. S., \& Çeçen, S. (2016). Scrutinizing practicum for a more powerful teacher education: A longitudinal study with pre- service teachers. Educational Sciences: Theory and Practice, 16(1), 127-151. https://doi.org/10.12738/estp.2016.1.0207.

Varela, D. G., \& Desiderio, M. F. (2020). Perceptions of COVID-19 pandemic impact on the student teaching experience. Research in Higher Education Journal, 39, 1-12. https://www.aabri.com/manuscripts/203267. pdf.

Weschke, B., Barclay, R. D., \& Vandersall, K. (2011). Online teacher education: Exploring the impact of a reading and literacy program on student learning. Journal of Asynchronous Learning Networks, 15(2), 22-43. https://doi.org/10.24059/olj.v15i2.174.

Yangin Eksi, G., \& Gungor, M. N. (2018). Exploring the use of narratives to understand preservice teachers' practicum experiences from a sociocultural perspective. Australian Journal of Teacher Education, 43(4), 159-174. http://dx.doi.org/10.14221/ajte.2018v43n4.9.

Yüksel, İ., \& Uysal, B. C. B. (2021). Foreign language education through online communities of practice. In C. H. Xiang (Ed.), Trends and developments for the future of language education in higher education (p.141-165). IGI Global. DOI: 10.4018/978-1-7998-7226-9.ch008.

Zhang, W., Wang, Y., Yang, L., \& Wang, C. (2020). Suspending classes without stopping learning: China's education emergency management policy in the COVID-19 outbreak. Journal of Risk and Financial Management, 13(3), 1-6. https://doi.org/10.3390/jrfm13030055. 